\title{
Lexical Variation in Akokoid
}

\author{
Fádorò, Jacob Oludare \\ Department of Linguistics and African Languages, \\ University of Ibadan, Nigeria \\ E-mail: oluyemidare@yahoo.com,oluyemidare7@gmail.com
}

Received: 15-02- 2014

Accepted: 01-04- 2014

Published: 01-07- 2014

doi:10.7575/aiac.ijalel.v.3n.4p.198

\begin{abstract}
Language contact among Akokoid, Yoruboid and Edoid has resulted in extensive borrowing from Yoruboid and Edoid to Akokoid. Thus, the speech forms subsumed under Akokoid exhibit lexical items which are similar to Yoruboid and Edoid. To the best of our knowledge, no other scholarly work has addressed the concept 'lexical variation in these speech forms, hence, the need for this present effort. Twenty lexical items were carefully selected for analysis in this paper. Data were elicited from 34 informants who are competent speakers of Akokoid. Apart from the linguistic data, these informants, including traditional rulers, supplied us with historical facts about the migration patterns of the progenitors of Akokoid. The historical facts coupled with the linguistic data helped us to arrive at the conclusion that some of the words used in contemporary Akokoid found their way into Akokoid as a result of the contact between Akokoid and their neighbours, Yoruboid and Edoid.
\end{abstract}

Keywords: Akokoid, Language Contact, Lexical Variation, Yoruboid, Edoid

\section{Introduction}

\subsection{The Sociolinguistic Situation in Akokoid}

As hinted in Fadọrọ̀, 2010 \& 2012, Akoko is the most linguistically diverse area of Yorùbáland. In addition to Yorùbá, there are several other languages spoken natively in the area. These languages belong to four language sub-groups of the Benue Congo. See table 1 below:

Table 1. Benue Congo Languages Spoken in Akokoland according to Subgroups

\begin{tabular}{lll}
\hline \multicolumn{2}{c}{ Language Groups } & \multicolumn{1}{c}{ Varieties in Akokoland } \\
\hline 1. & The Yoruboid & Oka, Ikare, Iboropa, Akungba, Ifira, Oba, Ikun, Supare, Irun, Afin \\
2. & Arigidi Cluster (Akokoid) & $\begin{array}{l}\text { Arigidi (Comprising Arigidi And Erushu), Owọn (Comprising Afa, } \\
\text { Aje, Udo, Oge, Oyin, Igashi and uro), Ahan, Ojo }\end{array}$ \\
3. Akpes & $\begin{array}{l}\text { Akpes (Akunnu), Ase, Daja, Esuku, Gedegede, Ibaram, Ikaram } \\
\text { (Ikorom), Iyani }\end{array}$ \\
4. Ukaan (Ikani) & $\begin{array}{l}\text { Auga (ligau), Ise (Ishieu), Kakumo-Akoko (Ikaan), Ayanran (Iyinno) } \\
\text { (Ayaran is spoken in Edo State) }\end{array}$ \\
5. Edoid & Ehueun (Ekpinmi), Uhami (Ishua), Ukue. \\
\hline
\end{tabular}

Of all these languages, Yorùbá is incontrovertibly the most dominant. Its influence on the Akokoid speech forms is more pervasive than any other one. The reason for this is not far-fetched. Akokoid speakers live among the larger community who are speakers of Yorùbá. In fact, Fadọrọ̀, (2010) asserted that majority of these Akokoid speakers prefer Yorùbá to their speech forms because of four factors. These are: Economic, Demographic, Institutional Support and Historical factors.

All these factors taken together agree both in theory and practice with Giles et al (1977) on the factors for promoting ethnolinguistic vitality. Let us discuss them one after the other. In the first place, these people regard their ancestral home as Ilé-Ifẹe (Beely 1934; Babalola 1984; Abiodun 2000; Akere 1982; Oyetade 2007 \& Dada 2006). As a result of this, they consider Yorùbá as a mark of identification and link with their ancestral home. Also in terms of geographical location they are surrounded by Yorùbá speakers. These two reasons are historical, sentimental and demographic.

On the other hand, Yorùbá is learnt for instrumental and economic reasons. This is because; the language offers them some benefits. They believe that their proficiency in Yorùbá would afford them the opportunity to communicate and be accepted by other Yorùbá speakers. Furthermore, knowledge of Yorùbá is considered a boost to their trades. Moreover, its knowledge would facilitate easier and faster learning for their children in school, since Yorùbá is the medium of 
instruction in the early years of primary school (i.e. primary $1-3$ ). This is in accordance with the 1977 National Policy on Education in Nigeria and its revision in 1981.

Finally, in all formal contexts like churches, Mosques, social institutions and service centres, such as hospitals, post offices, police stations, local government headquarters. Yorùbá is mostly used. In fact, we visited the Akoko North West Local Government Headquarters at Oke-Agbe twice and spent several hours there in the course of this research. Our observation was that Yorùbá was used virtually for all kinds of communication (official or personal) English language and the different tongues of the interlocutors were sparingly used.

\subsubsection{Classification}

Our Akokoid comprises nine related speech-forms spoken in Akoko area of Ondo State in South-Western Nigeria. These speech forms have been given different names by scholars. Hoffman (1974) referred to them as Northern Akoko Cluster; Akinkugbe (1978) referred to them as Akokoid; Capo (1989) referred to them as Amgbe; Akinyemi (2002) referred to them as Arigidi-Amgbe, while Fadọrọ` (2010) \& (2012) referred to them as Arigidi-Ộwọ̀n. Fádọrọ̀’s classification is on the bases of mutual intelligibility and lexicostatistics. These nine speech forms are Arigidi, spoken in Arigidi town; Erushu, spoken in Erushu town; Uro, spoken in Uro Ajowa; Igashi, spoken in Igashi community; Oyin, spoken in Oyin community and Oge, Aje, Udo and Afa, all spoken in Oke-Agbe. These nine speech forms are all spoken in Akoko North West Local Government in Oke-Agbe by over 250,000 people, according to 2006 census in Nigeria. See the tree diagram below:

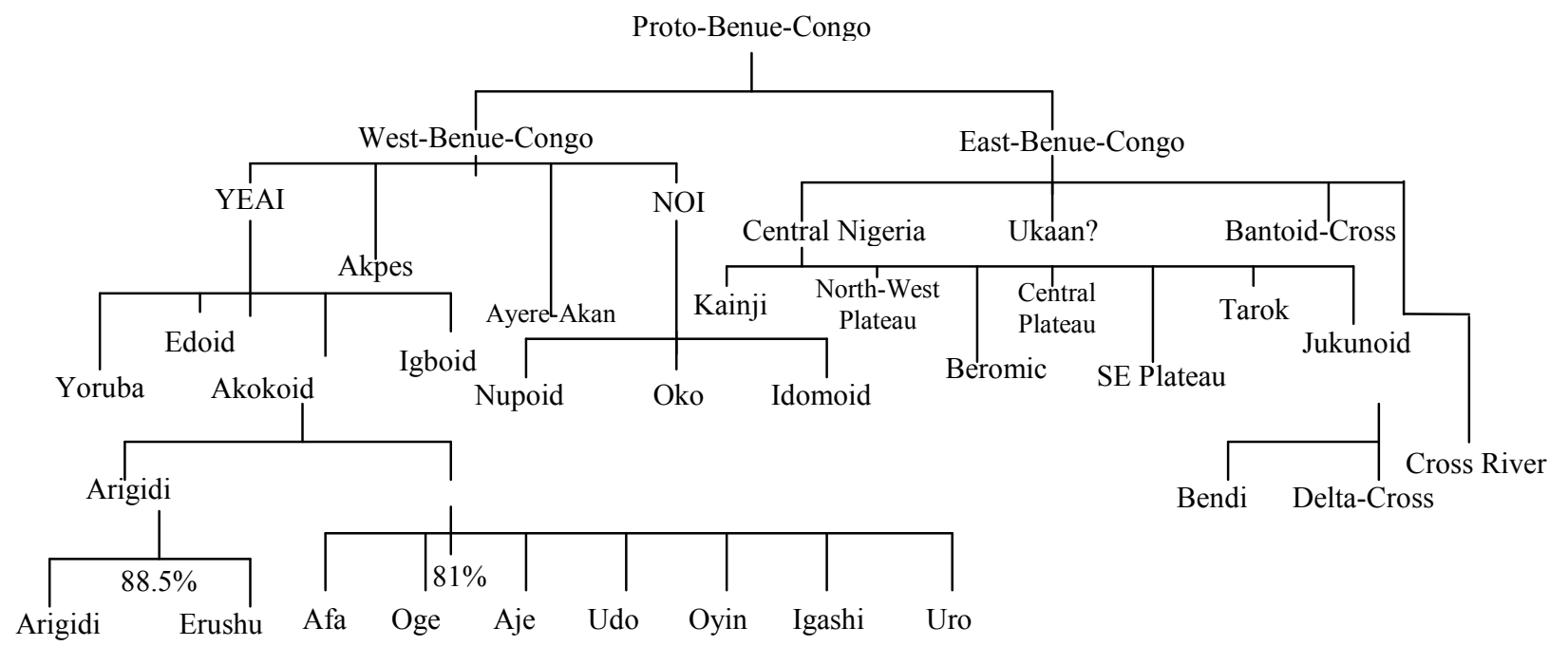

\section{Structural Variations in Language}

Regional dialects sometimes exhibit differences in the words people use for the same object. These differences are referred to as variations. At the structural level, three kinds of variations are identified. These are phonological, lexical and syntactic variations. Even though this paper focuses on lexical variation in Akokoid, we need to briefly discuss the three types of variation.

\subsection{Phonological Variation}

This occurs when two words which on the surface appear different, but actually sound alike are used to refer to the same object. This similarity may affect the consonants or the vowels used in the words. It may also affect the tones that are used, if the language is a tonal language. Let us cite a few examples below:

Table 2. Phonological Variant

\begin{tabular}{|c|c|c|c|}
\hline & Arigidi & Owon & Gloss \\
\hline i. & egíri & igíri & Head \\
\hline ii. & Ed3e & idze & Body \\
\hline iii. & Efo & itfi & Kolanut \\
\hline iv. & etfo & it & Fire \\
\hline v. & Ėgú & ìgú & Town \\
\hline vi & Ebú & ibú & Mortar \\
\hline
\end{tabular}


A look at the table above shows that the words for each item are phonetically and phonologically related. In all the items ( $\mathrm{i}$ - vi) 'e' in Arigidi alternates with ' $i$ ' in $\mathrm{O}$ )wo)n i.e. e ò $\mathrm{i}$. In item (iii) ' $\mathrm{S}$ ' in Arigidi alternates with 'tS' in $\mathrm{O})$ wo)n. In (d) ' $t S$ ' in Arigidi alternates with ' $t$ ' in $\mathrm{O}$ )wo)n i.e. $\mathrm{tS}$ ò t. all these are instances of phonological variation.

\subsubsection{Lexical Variation}

This occurs when two words which are neither phonetically nor phonologically related are used to refer to the same object. That is, the two words are clearly different, yet they are used to refer to the same object. Hans Kurath, an eminent dialectologist in his paper entitled: "What do you call it? Captures lexical variation as follows:

Do you call it a pail or a bucket? Do you draw water from a faucet or from spigot? Do you pull down the blinds, or the shades or the curtains when it gets dark? Do you wheel the baby, or do you ride it or roll it in a baby carriage, a buggy, a coach or a cab?

In the above assertion, two varieties of English are exemplified by the different lexical items they use to refer to the same items. We can summarise this in the table below:

Table 3. Lexical Variants in English

\begin{tabular}{ll}
\hline Variety A & Variety B \\
\hline Pail & Bucket \\
Spigot & Faucet \\
Blinds & Shades \\
Roll & Wheel \\
Buggy & Coach \\
\hline
\end{tabular}

These words obviously do not sound alike, yet, they refer to the same items. They are examples of lexical variation.

\subsubsection{Syntactic Variation}

While phonological and lexical variations affect individual words, syntactic variation affects more than an individual item. It affects phrases, clauses or a whole sentence. Let us exemplify this with Yorùbá language spoken in the South Western Nigeria. We will use the standard variety, referred to as Standard Yorùbá (SY) and İjẹsà dialect, one of the varieties identified as Central Yorùbá (CY). See Akinkugbe (1978).

Table 4. Syntactic Variants in Yorùbá

\begin{tabular}{|l|l|l|}
\hline SY & CY & Gloss \\
\hline Tanì yẹn? & Yèsí erè? & Who is that? \\
\hline Kínì yẹn? & Kí erè? & What is that? \\
\hline Kò lõ & Éẽ lõ & He did not go \\
\hline Olú gbin ibẹ́pẹ & Olú gbẹ gbẹ̀gbẹ̀rẹ̀ & Olú planted pawpaw \\
\hline Kí ló dé? & Kó tií rí? & What happened? \\
\hline
\end{tabular}

In the above examples, the differences affect the whole sentences. These are instances of syntactic variation. Having briefly examined the different levels of variation, we shall focus on lexical variation which is the main preoccupation of this paper. First, we shall look at causes of lexical variation in general and then present our data in Akokoid with detailed discussion.

\subsubsection{Causes of Lexical Variation}

New lexical items find their way into language as new objects appear. Existing words either retain their old meanings or expand their coverage. Francis (1983) observes that lexical variation, whether involving different words or different meanings for the same words, is not confined to new things which must be named. Often it deals with common matters of everyday life and goes back a long time in the history of the language. A common cause which has been identified by linguists is contact with another language, from which familiar words are borrowed.

Fromkin \& Rodman (1993) expatiated on the above point with regard to English Language. According to them:

Until the Norman Conquest when an Englishman slaughtered an ox for food, he ate ox. If it was a sheep, he ate sheep. However, ox served at Norman's table was beef, pig was pork and sheep was mutton.

Fromkin \& Rodman (1993: 333) 
The above quotation points out clearly that lexical variations occur in English as a result of contact with Norman (a variety of French).

Secondly, the scholars also opine that lexical variation arises through loss of words. Just as new words find their way into a language, words also can be lost from a language, especially if the speakers are not in regular contact. They cited the work of Shakespeare to illustrate this point. According to them, examples of words found in Shakespeare's English which have been lost are:

$\begin{array}{lll}\text { Beseem - } & \text { 'to be suitable' } \\ \text { Fain } & - & \text { 'gladly' } \\ \text { Gyve } & - & \text { 'a fetter' } \\ \text { Wherefore } & - & \text { 'why' (pp 336) }\end{array}$

Just as it happened in English, other languages and dialects experience loss of words from time to time and this process may not spread across all the dialects of a language, especially if the speakers are not in regular contact. With specific reference to Akokoid, this must have instigated some of the lexical variants that are attested.

Thirdly, semantic change which may take the form of broadening or narrowing can instigate lexical variation. Broadening takes place when the meaning of a word becomes broader, that is, that word means everything it used to mean, as well as other things. For instance, 'dogge' in Old English meant a specific breed of dog, but it was eventually broadened to encompass all members of the specie, 'Canis familiars'. The word 'holiday' originally meant 'holy day" a day of religious significance. Today, the word means any day on which we do not have to work. In Yorùbá language, the word 'oko' originally meant farm, but nowadays, the meaning can be extended to cover 'rural areas', 'transport trips', etc. The same thing applies to the word 'ojà' which originally meant 'market.' People now use it to cover 'sales' 'goods', etc. The word 'aye*ta' originally meant bullet proof, but now some people use it to mean contraceptives. Narrowing, on the other hand takes place when the meaning of a word reduces. In other words, its meaning has a restricted scope compared with what obtained in the past. We have instances of this process in the Bible. The word 'meat' meant 'food' to a seventeenth-century speaker of English, while the word flesh meant 'meat'. However, semantic change has narrowed the meaning of 'meat' to what it is in modern English. The word 'deer' once meant 'beast' or 'animal' as its German related word 'tier' still does. The meaning of 'deer' has been narrowed to a particular kind of animal. The word 'bread' in the Lord's Prayer: 'give us our daily bread" was used to depict; food' however, 'bread' is a specific kind of baked food in contemporary English (Fromkin \& Rodman 1993).

Finally, meaning shift also occasions lexical variation in languages. The word 'bead' originally meant 'prayer'. Nowadays the meaning has shifted from prayer to the visible sign of prayer - 'rosary'. The word 'silly' used to mean 'happy' in old English, in Middle English 'naïve'. Now it means 'foolish'. All these instances clearly support the claim that language is not monolithic.

\section{Data Presentation}

Table 5. Lexical Variants in Akokoid [Data Presentation]

\begin{tabular}{|c|c|c|c|c|}
\hline & Gloss & Variant & Places where used & Likely Source (s) \\
\hline 1. & \begin{tabular}{|l|} 
Cotton \\
wool \\
\end{tabular} & $\begin{array}{l}\text { (a) ơwú } \\
\text { (b) orúru }\end{array}$ & $\begin{array}{l}\text { Uro and Igashi } \\
\text { All others }\end{array}$ & $\begin{array}{l}\text { (a) Yorùbá (Ówú) } \\
\text { (b) Edo (Orüru) }\end{array}$ \\
\hline 2. & Hawk & $\begin{array}{l}\text { (a) àpồò̀ } \\
\text { (b) àkúnùdù } \\
\text { (c) îti } \\
\text { (d) ìg } \\
\text { (e) èsise }\end{array}$ & $\begin{array}{l}\text { Oge, Udo, Erushu, Afa, Aje } \\
\text { Uro } \\
\text { Arigidi } \\
\text { Oyin } \\
\text { Igashi }\end{array}$ & (a) Edo (ákpukpo) \\
\hline$\overline{3 .}$ & Lizard & $\begin{array}{l}\text { (a) ùls } \\
\text { (b) okkots }\end{array}$ & $\begin{array}{l}\text { Igashi } \\
\text { Others }\end{array}$ & (b) Edo (òkidô) \\
\hline 4. & Cap & $\begin{array}{l}\text { (a) ewà } \\
\text { (b) ivas } \\
\text { (c) idú }\end{array}$ & $\begin{array}{l}\text { Arigidi } \\
\text { Enushu } \\
\text { Others }\end{array}$ & (c) Edo (idú) \\
\hline 5. & Kill & $\begin{array}{l}\text { (a) kó } \\
\text { (b) kpó } \\
\text { (c) kpú }\end{array}$ & $\begin{array}{l}\text { Arigidi } \\
\text { Enushu and Aje } \\
\text { Others }\end{array}$ & $\begin{array}{l}a-c \\
\text { Yorúbá (kpa) }\end{array}$ \\
\hline 6. & Vomit & $\begin{array}{l}\text { (a) kpà } \\
\text { (b) pà }\end{array}$ & $\begin{array}{l}\text { Arigidi, Erushu, Aja } \\
\text { Others }\end{array}$ & $\begin{array}{l}\text { a-b } \\
\text { Edo (pá) }\end{array}$ \\
\hline 7. & Roast & $\begin{array}{l}\text { (a) tyáa } \\
\text { (b) tû́ } \\
\text { (c) sũ } \\
\text { (d) tá }\end{array}$ & $\begin{array}{l}\text { Arigidi, Enushu } \\
\text { Afa, Udo } \\
\text { Oyin, Oge and Aje } \\
\text { Igashi and Uro }\end{array}$ & $\begin{array}{l}\text { a-d Yonùbá } \\
\text { (sū) }\end{array}$ \\
\hline 8. & Mould & $\begin{array}{l}\text { (a) } \mathrm{ms} \\
\text { (b) } \mathrm{ma}\end{array}$ & $\begin{array}{l}\text { Arigidi, Erushu } \\
\text { Others }\end{array}$ & $\begin{array}{l}\text { ałb Yorùbá } \\
\text { (m5) }\end{array}$ \\
\hline 9. & Nose & 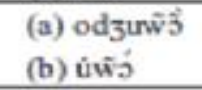 & $\begin{array}{l}\text { Arigidi } \\
\text { Others }\end{array}$ & $\begin{array}{l}\text { a-Edo } \\
\text { (úw5) }\end{array}$ \\
\hline 10 & Bird & (a) $\mathfrak{x} \tilde{x}$ & Others & a-Edo \\
\hline
\end{tabular}




\begin{tabular}{|c|c|c|c|c|}
\hline & & (b) âka & Oge, Uro & (Sura) \\
\hline 11 & Tortoise & $\begin{array}{l}\text { (a) abふ்hã } \\
\text { (b) agógo }\end{array}$ & Arigidi, Erushu & $\begin{array}{l}\text { (a) Yorùbá } \\
\text { (obahû) }\end{array}$ \\
\hline 12 & Chief & $\begin{array}{l}\text { (a) irçnĩ } \\
\text { (b) idjōòjè }\end{array}$ & $\begin{array}{l}\text { Oge. Uro } \\
\text { Others }\end{array}$ & $\begin{array}{l}\text { (b) Yorùbá } \\
\text { (Adj3ojè) }\end{array}$ \\
\hline 13 & Crab & $\begin{array}{l}\text { (a) ãkổ } \\
\text { (b) anyá }\end{array}$ & $\begin{array}{l}\text { Arigidi, Erushu } \\
\text { Others }\end{array}$ & $\begin{array}{l}\text { (a) Yorùbá } \\
\text { (alákj̉) }\end{array}$ \\
\hline 14 & Bee & $\begin{array}{l}\text { (a) Ggî } \\
\text { (b) uwi }\end{array}$ & $\begin{array}{l}\text { Arigid, Uro, Afa } \\
\text { Others }\end{array}$ & $\begin{array}{l}\text { (c) Yorùbá } \\
\text { (oji) }\end{array}$ \\
\hline 15 & Cassava & $\begin{array}{l}\text { (a) ذ̇gbörödö } \\
\text { (b) ذ̀gônòlò } \\
\text { (c) kpâki }\end{array}$ & $\begin{array}{l}\text { Uro } \\
\text { Others } \\
\text { All the speech forms }\end{array}$ & $\begin{array}{l}\text { (c) Yorìbai } \\
\text { (kpáki) }\end{array}$ \\
\hline 16 & Cow & $\begin{array}{l}\text { (a) màlứ } \\
\text { (b) arago }\end{array}$ & $\begin{array}{l}\text { Igashi and Aje } \\
\text { Others }\end{array}$ & $\begin{array}{l}\text { (a) Yorùbá } \\
\text { (màtùu) }\end{array}$ \\
\hline 17 & Cat & $\begin{array}{l}\text { (a) músù } \\
\text { (b) ológbò }\end{array}$ & $\begin{array}{l}\text { All the speech forms } \\
\text { All the speech forms }\end{array}$ & $\begin{array}{l}\mathrm{a}-\mathrm{b} \\
\text { Yorùbấ músù (ológbò) }\end{array}$ \\
\hline 18 & Snail & $\begin{array}{l}\text { (a) àkúrú } \\
\text { (b) igbí }\end{array}$ & $\begin{array}{l}\text { Oge, Uro, Aje and Igashi } \\
\text { Others }\end{array}$ & $\begin{array}{l}\text { (b) Yorùbá } \\
\text { (igbí) }\end{array}$ \\
\hline 19 & Yam & $\begin{array}{l}\text { (a) adju } \\
\text { (b) aju } \\
\text { (c) iti } \\
\text { (d) itfe } \\
\text { (c) efe } \\
\text { (f) isi }\end{array}$ & $\begin{array}{l}\text { Oyin, Afa } \\
\text { Udo } \\
\text { Igashi } \\
\text { Erushu } \\
\text { Arigidi } \\
\text { Oge, Uro, Aje }\end{array}$ & $\begin{array}{l}\text { Items a-f could possibly } \\
\text { be traced to Yorübá } \\
\text { "ifu". }\end{array}$ \\
\hline 20 & Toad & $\begin{array}{l}\text { (a) okpols } \\
\text { (b) aboto }\end{array}$ & $\begin{array}{l}\text { All the others } \\
\text { Aje }\end{array}$ & $\begin{array}{l}\text { Yorùbál } \\
\text { (jikpoilí) }\end{array}$ \\
\hline
\end{tabular}

In the table above, we exemplified lexical variants in the Akokoid speech forms. As indicated in the analysis, some of the words that feature prominently as lexical variants are found in other languages, especially Yorùbá and Edoid. This implies that they could be traced to contact with these languages. Let us cite a few examples. The following words: king, cow, cat, cassava, toad, tortoise, crab, bee, snail, etc in the table above point towards the possibility of influence of Yorùbá on Akokoid as a result of the contact between the speakers. Likewise, the following words: bird, cotton, lizard, hawk, cat, etc above indicate the possibility of influence of neighbouring Edo languages. Let us capture the latter more vividly by examining the table below.

Table 6. Akokoid and Edoid Compared

\begin{tabular}{|c|c|c|}
\hline Gloss & Akokoid & Edoid \\
\hline Cotton & Oruru & oruru \\
\hline Lizard & jk kàtò & ókido \\
\hline Bird & วิrā & Sura \\
\hline Nose & น์พัวี & úwีย \\
\hline Hawk & àpòpỏ & ákpukpə \\
\hline Cap & idū & ètù \\
\hline Year & ēbō & $\bar{e} z \bar{o}$ \\
\hline Kill & kpú & kpé \\
\hline Roast & tũ & tō \\
\hline Mould & mä & mā \\
\hline Vomit & kpà & kpa \\
\hline
\end{tabular}


A look at the above items reveals a striking similarity. It would not be out of place if one describes them as cognates. Morphologically speaking, the Yoruboid, Edoid and Akokoid languages are related. There is no occurrence of consonant cluster in the languages. Three phonetic syllable structures could be identified in these languages. These are V, CV and N (syllabic Nasal). Fado)ro) (2010) discussed these in some details. Apart from this, the languages Yoruboid Akokoid and Edoid are sisters. They are all daughters of the West -Benue Congo of Williamson \&Blench (2000). See Fig. 1 above.

Two major factors could be held accountable for this. First, the migration pattern of the speakers of Akokoid reveals that they traced their ancestral homes to both Ile-Ife and Benin. Second, their present geographical settlements pitch them between the speakers of Yorùbá and Edoid languages. Apart from these two factors, we explained above that, speakers of these Akokoid speech forms are bilingual in Yorùbá and their respective Akoko languages. This has been extensively discussed in Oyetade (2007).

\section{Conclusion}

We conclude with the following assertions as expressed by Elugbe \& Bankale (2004: 3) as follows:

It is not quite clear what the difference is between 'geographic proximity' and 'borrowing' in terms of linguistic relationships. We would normally assume that proximity begets contacts and contact begets borrowing or influence.

In other words, the lexical variants that are attested in our analysis above could be attributed to external influence as a result of contact with other languages. What is not quite clear is the direction of influence. Is it that Akokoid influenced Yorùbá and Edoid or is it the other way round? Egbokhare (2008) (Personal Communication) opines that the first option is a possibility. According to him one should not always assume that the smaller languages are influenced by the bigger ones, bigger languages may also influence smaller ones. For example, English has borrowed extensively from French, Spanish and Japanesse. However, it is very unlikely that Yoruba would borrow from Akokoid. The converse is likely to be the case since these people speak Yoruba as their second language and they are as proficient in Yoruba as they are in their native languages. In fact, Oyetade (2007) reports that some of them, especially the youths, are more proficient in Yoruba than their various Akokoid languages.

\section{References}

Abiodun, M.A. (2000). A preliminary report on the linguistic relationship between Ahan and Ayere. Paper Presented at the $24^{\text {th }}$ West African Languages Congress, Nigeria.

Akere, F. (1982). Language use and language attitude in a Yorùbá suburban town: a sociolinguistic response to the factors of traditionalism and modernity. Anthropological Linguistics (14 (3): 344-67).

Akinkugbe, O.O. (1978). A comparative phonology of Yorùbá dialects, Itsekiri and Igala. Ph.D thesis, University of Ibadan.

Akinyemi, O.V. (2002). A study of the internal relationship within Northern Akokoid Unpublished B.A. Project, University of Ibadan.

Babalola, E.O. (1984). The Nupe factor in Nigerian Islamic history: the Akoko Example, Orita, (16(2) 98-110).

Beeley, J.H. (1934). Intelligence Report on the Akoko District, N.A.I.C.S.I. CSO 2629667.

Capo, H. B.C. (1989). Defoid, The Niger-Congo Languages, J. Bendor-Samuel Ed. New York and London: University Press of America. (Pp. 275 - 90).

Dada, S.A. (2006). Erushu-Yorùbá endoglossic bilingualism and language alternation in Akoko, south-western Nigeria. Unpublished Ph.D. thesis, University of Ibadan.

Elugbe, B.O. \& T. Bankale (2004). Cognation percentages in Benue-Congo: implications for internal classification. Proceedings, 4th World Congress of African Linguistics. A. Akinlabi ed. New Brunswick.

Fádọọ̣, J.O. (2010). Phonological and Lexical Variations in Akokoid. Unpublished Ph.D Thesis, Department of Linguistics and African Languages, University of Ibadan.

Fádộọ̀, J.O. (2012). 'Towards Akokoid Orthographies' in Ayo)o)la, K.A. (ed.). Papers in English and Linguistics (PEL) (Vol. 13, pp. 223-240).

Francis, W.N. (1983). Dialectology: An Introduction. New York: Longman.

Fromkin, V. \& R. Rodman (1993). An introduction to language. (5 $5^{\text {th }}$ edition): Harcourt Brace Jovanovich.

Giles, H., R. Y. Bourhis, \& D. M. Taylor, (1977). Towards a theory of language in ethnic group relations. Giles H. Ed. Language, ethnicity and inter-group relations, London: Academic Press. (Pp.307-49).

Hoffman, C. (1974). The languages of Nigeria by language family. An index of Nigerian languages, H.J. BendorSamuel \& R. Stanford (Eds.) Ghana: Summer Institute of Linguistics, (pp. 169 - 190).

Oyetade, S.O. (2007). Language endangerment in Nigeria: perspectives on Akoko languages of the Southwest. Dorian. N.C., (ed.) Small languages and small language communities. Int'l. Journal of Sociology of Language. (Pp. 169 - 184). 